\title{
TITLE BY LIMITATION IN A REGISTERED CONVEYANCING SYSTEM
}

\author{
JEREMY S. WILLIAMS*
}

The law of Alberta differs from that of the other Canadian Provinces in that it enables squatters to gain a title to land. This seems to be incompatible uith the purpose of the Torrens System.

The law relating to limitation of actions is more procedural than substantive in that its chief purpose is to remove a remedy, but not to affect the right.' The Limitation Act is not concerned with the merits of any particular case but simply ensures an end to litigation. The periods of time within which an action to recover land may be brought have been various but have always been prescribed by statute. The earliest statute with this aim was the Statute of Merton which was enacted in 1235. The present Alberta statute, the Limitation of Actions Act, R.S.A. 1955, chapter 177, is typical of modern statutory provisions. By section 18 it provides that no person shall take proceedings to recover land except within ten years next after the right to do so first accrued to such person, or if the right to recover first accrued to a predecessor in title, then within ten years next after the right accrued to such predecessor. Thus, the statute discourages delay on the part of a claimant, but does nothing to divest him of his right. Although the rules relating to limitation of actions may be said to operate negative$\mathrm{ly}$, the lapse of the statutory time period eliminates the chance of the occupier being ousted by a person having a superior title. Apart from consideration of the Torrens System, as embodied in the various Land Titles Acts, the common law rule is still that possession is a root of title because possession of land, unless otherwise explained, is evidence of seisin in fee simple. Thus if all those having a better right to possession than the occupier were prevented from prosecuting their claims the position of the occupier would be virtually unassailable. Therefore, at common law, to prove ownership one demonstrated possession for such a length of time as would limit any adverse claim.

Because an owner dispossessed for more than the statutory period could not eject the tenant by physical force or law suit, his ownership was emasculated. Nevertheless, if he could regain possession by lawful means it would be impossible for the squatter to oust him. For as between himself and the squatter, the owner had the better right to possession. This exemplifies the distinction between the remedy and the right.

The current legislation does not permit competition even by one

- Jeremy S. Williams, LL.B. (Sheffield), B.C.L. IOxon.l. Assistant Professor. The Univerisity of Albertia.

IIt is generally said that whereas limitation is wholly statutory and. in orisin, extinctive in naturc, prescription is a common law doctrine and allow's acquisition of casements and profits-a-prendre over the land of another. In Albert3, section 49 of the Limitation of Actions Act. R.S.A. 1955, c. 177. provides that ccrtain specified incorporeal hereditaments may not be acquired by prescription. A similar provision exists in the Saskatchewan Land Titles Act. R.S.S. 1965, c. 115. s. 71. See also s. 31 Limitation Act, R.S.O. 1960. c. 214 . 
who is prevented from prosecuting his claim.: The modern statutes not only bar the remedy but destroy the right." The Alberta Limitation of Actions Act" by sec. 44 prescribes that, "At the determination of the period limited by this Act to any person for taking proceedings to recover any land, rent charge or money charged on land the right and title of such person to the land, or rent charge or the recovery of the money out of the land is extinguished."

It is clear that there is a basic incompatibility between the policy of allowing the acquisition of title by limitation and the Land Titles Act" the avowed aim of which is to allow complete reliance on the register. Sec. 65 of the Alberta Land Titles Act" declares that, "every certificate of title ... is conclusive evidence in all courts ... that the person named therein is entitled to the land included in the same for the estate or interest therein specified ..." However, any squatter who occupied for the statutory period would gain a title which was not shown on any certificate or on the register. This would. prima facie, hinder full reliance on such certificates. At least, it would be necessary for a prospective purchaser or mortgagee to inspect the land. Thus, the question arises, which is to prevail; the Land Titles scheme or the principle of title by limitation?

The case of Belize Estate \& Produce Co. v. Quilteri raised the same issue when it was presented to the Judicial Committee of the Privy Council in 1897. Lord Watson delivered the advice of the Committee which depended very largely on construction of the statutory provisions involved. Their view was that, "the right and title of the true proprietor of land, which is and has been the subject of adverse possession by one having no title of property, to bring a suit for recovery of possession is absolutely extinguished by the lapse of the statutory period . . ." It is not clear whether their Lordships conceived that the two statutes could work in harmony or whether the Limitation Act prevailed over the Land Registry Act. The British Honduras Land Registry Act differs from many modern Torrens Systems in that it was there at the option of any given owner whether he would have his title registered. Therefore, since registration was virtually an afterthought, there would not

: The Imperial Legislature in 1833 enacted the Real Property Limitation Act. 3 \& 4 Will. 4. c. 27. s. 34 of which provided that at the expiry of the limitation period both the right to bring oction to recover the land and the title thereto should be extinguished. Sec. 9 of the Real Property Limitation Act. 1874, rc-cnacted this provision, and in its turn was incorporated as part of the law of Alberta by sec. 2 of c. 31 of the Consolidated Ordinances, 1898.

a E.g. S. 16 of the English Limitation Act, 1939; s. 15 Limitation Act. R.S.O. 1960. c. 214: s. 44 Limitation Act. R.S.M. 1954. c. 145; s. 60 Limltation Act. R.S.N.B. 152. c. 133.

+ R.S.A. 1955, c. 177.

1a The common lav position as aitered by this provision is exemplified by Re Anderton (1908), 8 W.L.R. 319. where the question was: "who was to be registered as the owner on first registration when the occu!sler claimed to be entitled?" Stuart, J. held that the applicant was not entitled to be registered as owner for there was no evidence as to who the true owner was at the commenecment of the statutory period. However. Stuart. J. did state. "I am clearly of the opinion that, by the effect of the statute. after the proper period of limitation has passed. the lezal fee simple is in the party who has been in possession during that period. and that he is compctent to convey it to another..." This obiter dictum was applied in Bradshau v. Pattersun 11911). 18 W.L.R. 402 where the land was not then registered under the Saskatchewan Land Titles Act. In the latter case the judgment of Lamont. J. declared that the rights of the defendants in the land had been extinguished and that the plaintiff occupler was cntitled.

31955 R.S.A.. c. 170.

" Similar provisions occur in other registration statutes, e.g. S. 69 of the English Land Registration Act, 1925.

$7|1897|$ A.C. 367 . This was an appeal from the Supreme Court of British Honduras and was concerned with apparent conflict between the Limitation Act and the Titles Registry Act of that jurisdiction. 
be such a reverence for the register as there would be in a system where almost all dealings with titles must be registered before they become effective. This is a consideration not adverted to by the judges who took this as the fons et origo of the modern Alberta position. Lord Watson stated further that," "Their Lordships are unable to discover either in sec. 30 or in any other clause of the [Land Titles Registry] Act, a single expression indicating that the Legislature meant to deal with any question of possession." This statement has been adverted to in more recent decisions.

The Supreme Court of Canada has rejected the application of Belize Estate v. Quilter to the Manitoba legislation on the ground that the wording of sec. 75 of the Manitoba Real Property Act expressly excludes the operation of the Limitations Act." The Supreme Court also found the Privy Council's decision inapplicable in Ontario, when in Gatz v. Kiziw'" it held that the clearest statutory language had been used to avoid such an eventuality. Since 1913, the position in Saskatchewan has been similar to that obtaining in Manitoba." The Land Registry Act of British Columbia since 1905 has resembled those of Manitoba and Saskatchewan, and the same rejection of Belize Estate v. Quilter is found.

\section{The Modern Alberta Position}

Alberta took the opposite view with respect to the applicability of Belize Estate v. Quilter.'2 Clearly possessory interests may be acquired before first registration, and most of the Land Titles Acts specifically acknowledge this. ${ }^{3}$ but in Alberta title may be gained by ten years' possession adverse to a registered owner. In Harris v. Keith ${ }^{14}$ the plaintiff brought an action to recover land from a defendant who had been in possession for a period in excess of that prescribed by the current Statute of Limitations. Stuart, J. refused to disturb the possessor and declared that a difficult problem would have arisen had the defendant asked for a declaration of his title to the land. Stuart, J. thought the problem existed because, "There is not from beginning to end of our Land Titles Act any suggestion, as far as I can find, that the Act intended or attempted to deal with the question of actual possession. Questions of title alone were the subject-matter of the Act."': While this is probably true of the Land Titles Act, the statement overlooks the fact that possession and the right to possess are generally coextensive. The common law rule is that possession gives a good title against all those who do not have a better title. The fact of possession is prima facie evidence of seisin in fee simple. The aim of the Land Titles Act is to substitute the concept of "ownership" (which is unknown at common law) for the previous system of competing and relative

s Id., at 371 .

"Smith v. National Trust Co. (1812), 45 S.C.R. 618: See Thom's Canadian Torrens System, 183 (2nd ed. De Castri 1962).

111959 | S.C.R. 10.

11 In Saskatchewan the Limitation Ac: is expressly subjected to the provisions of the Land Titles Act: Limitation Act R.S.S. 1966. C. 84. s. 17. Conversely" in Enkland sec. 70 (1) (f) L.R.A. 1925 provides that the registered title is subordinate to "squatter's rights".

1: Supra, in. 7.

13 Such as S. $73(1)$ Land Tilles Act R.S.S. 1965, c. 115: s. 40 Land Titles Act R.S.O. 1960 , c. 204. Rules 19 and 20 of the English Land Registration Rules, 1925.

11 (1911), 16 W.L.R. 433.

1.5 Id., at 441. 
titles. The weakness of the decisions on the Act (and now of the Act itself) ${ }^{16}$ is that the older system of "the better right to possession" is also recognized.

The doctrine expounded in Belize Estate v. Quilter that provision for title by limitation was compatible with a registered conveyancing system, was mentioned with approval in several early Alberta decisions. It was not until 1913, in Wallace v. Potter ${ }^{17}$ that it was incorporated as ratio decidendi. In that case the plaintiff obtained a declaration that he was the owner in fee simple of land which he had obtained by adverse possession. Simmons, J. stated that, "The result is that the plaintiff has acquired a title to the land which cannot be attacked by the person actually registered as the owner and in whose name a certificate of title is now upon the register. The result is quite an anomalous one but the authority for removing the anomaly is in the Legislature and not in the Court." Simmons, J. granted the declaration of ownership, but refused to cancel the certificate of title on the ground that there was no authority in the Land Titles Act to do so. This impasse was in 1921 remedied by the addition of section 73 to the Alberta Land Titles Act which empowers the Registrar to cancel the certificate after a copy of the declaratory judgment has been filed. The present position is as Beck, J. stated in Brogden v. Brogden: 19 "upon the title of the registered owner becoming 'extinguished' by continuous possession for [10] years, as it does by virtue of the statutory limitation, the occupant is entitled to ask the court, in the exercise of its ordinary jurisdiction, to declare his title and, upon a judgment to that effect, procure himself to be registered as the owner of the land."

\section{Solecisms in Alberta}

Although it has often been declared that the Limitation Act should prevail over the Land Titles Act, acceptance of this idea has not been universal. The principle seems entrenched in the law of Alberta but the general impression left by the cases on the subject is one of judicial determination to circumscribe and confine the doctrine of title by limitation. This attitude is exemplified by Dobek v. Jennings, ${ }^{2 n}$ the facts of which strongly indicated that the occupier acknowledged the registered owner's title. However, the Appellate Division of the Supreme Court of Alberta held that even if there had been effective possession for the limitation period but the registered owner conveyed the land to a third party then the rights of the occupier in the land ceased. The court opined that the principle of the Land Titles Act was that registration alone gives or extinguishes title and that other rights might be protected by caveat (but if not so protected would be lost entirely). Harvey, C. J. A., delivering the judgment of the court, said," "It is clear, therefore that whatever right or interest the plaintiff may have acquired, if any, by his years of possession he lost completely upon the issue to the defendant of his certificate of title in August, 1925, there

10 Land Titles Act, R.S.A. 1955. c. 170, 73.

17 (1913), 10 D.L.R. 594, followed in Saturley v. Young, |1945| 3 W.W.R. 110.

18 Id., at 596 .

$19\lceil 1920 \mid 2$ W.W.R. 803, 810.

20 I928। 1 D.L.R. 736.

21 Id., at 738 . 
being no question of any fraud on the part of the defendant or even of knowledge of any claim of interest ..." It might have been preferable for the court to have decided simply that there was no adverse possession. In Boyczuk v. Perry"- the same court, relying on its previous decision in Dobek v. Jennings, required a similarly placed occupier to give up possession to recent purchases of the disputed area. O'Connor, J. A. delivered a strong dissenting judgment in which he expressed the view that this sort of claim was exactly what the Limitation Act aimed at preventing. He pointed out that section 18 of the Limitation of Actions Act": read "No person shall take proceeding to recover land except ... . (b) if the right to recover first accrued to a predecessor in title, then within ten years next after the right accrued to such predecessor." But the argument which counter-vailed was that the purchaser derived his title from the register and not from any predecessor. However, it is clear that at the expiry of the limitation period the registered owner loses his title." The courts have held that at this stage the squatter is entitled to have his title declared. So the registered proprietor has no title, and the occupier has but is liable to be defeated if the registered proprietor purports to convey the land. Thus the squatter may be divested of the title by the actions of one who has now no interest at all in the land. An alternative theory (which is not indicated in the judgments) may be that the squatter acquires latent rights which may ripen into full ownership when a declaratory judgment is obtained or may be protected in the meantime by a caveat. This should not be the case because the judgment could only declare rights which already existed. Possibly, such full ownership would only be obtained when the registered owner's certificate is cancelled and the squatter registered in his stead. However, the decisions which subordinate sec. 65 of the Land Titles Act to the Limitation of Actions Act necessarily imply that this is not the case, and sec. 73 of the Land Titles Act only enables the Registrar to make the register conform with reality.

The view that the registered owner's title is extinguished and that the occupier attains a new title at the end of the limitation period is the orthodox view and is supported by the majority of the cases. It derives additional strength from the decision of Simmons, J. in Shirtcliffe $v$. Lemon,"s where a squatter had possessed land for the statutory period then the registered owner had regained possession for a short time. The squatter (who now had title) was held entitled to remove the registered owner and to be quieted in possession of the land. Simmons, J. stated,"1i "It seems to me that where the title through possession comes into direct conflict with the Torrens title and overrides it to the extent of barring any right of possession of the registered owner that its provisions cannot be invoked subsequently so as to disturb what he has acquired under the limitation statute ..." He said further that the rights of the registered owner could not revive if such registered owner should regain possession for this would be an excessive curtailment of the Limitation Act.

22 (1948| 1 W.W.R. 495

23 R.S.A. 1955, c. 177.

2t Id., 8. 44 .

$25|1924| 1$ W.W.R. 1059, where he expressly refused to follow the different opinion of Walsh, J. in Sinclair v. McLellan, [1919] 2 W.W.R. 782.

28 Id., at 1061. 


\section{The Quality of Possession}

Only that area of land which is physically occupied will become subject to acquisition by adverse possession. This was demonstrated in Harris v. Keith ${ }^{27}$ where the defendant was held entitled to such part of the land as he had fenced and cultivated, but not to the land on which he merely let his horses out to pasture. Thus there will often be a claim by a squatter to a part of a registered proprietor's land where acts of adverse possession have not been done with respect to the whole area. A difficulty exists when acts of adverse possession are directed against part of the land partitioned laterally or horizontally, but not vertically. Examples would be: the taking of minerals, using a layer of gravel or top soil, or the extraction of oil or other fugaceous substances. There seems to be no definitive statement as to whether oil and gas in situ are capable of being owned as land. In Duncan v. Joslin ${ }^{28}$ Porter, J. A. adverted to the problem thus, "Whether there can be a prescriptive title to a fugaceous mineral such as petroleum and natural gas and related hydro-carbons without the substances themselves being brought into possession in the sense that they are and have been under the physical control of the claimants, is a question that need not now be dealt with. It is sufficient to say that the acts relied on by the appellants as supporting their claim to adverse possession fall far short of the kind of possession which the Limitation of Actions Act contemplates in that there has been no physical or legal possession or occupation at all, much less one that is exclusive, continuous, open and notorious." If acts of adverse possession are so prolonged and widespread as to amount to an occupation of the land then, even though the occupier has in mind only the minerals, he should be allowed to allege an exclusive possession of the land for, objectively, that is what his acts have amounted to. Acts so limited that they could not be said to be an occupation of the land would at common law be said to give rise to a profit a prendre for minerals are the appropriate subject of such a profit and not of a title by limitation. Although profits à prendre may be granted by the landowner. they may not be acquired by prescription. $.^{2 y}: 0$

Therefore, it would appear probable that claim would have to be laid to the land itself if a possessory or prescriptive title was to be claimed and that one could not allege ownership by limitation of minerals alone. Of course, when once minerals (fugaceous or otherwise) are severed from the realty the law relating to land ceases to apply and one could be said to possess them in a real sense. The comments about minerals will probably be applicable to all substances, organic or inorganic, the retrieval of which does not entail occupation of a definable area of the earth's surface.

A squatter may avail himself of the adverse possession of one under his control, such as an agent or servant. A widow whose husband had

ㄱ $|1910-1| 1 \mid 16$ W.L.R. 433.

2: I1965I, 51 W.W.R. 346, at 349: see also Turta v Imperial Oil Co. 12 W.W.R. (N.S.) 97. per Rand. J. at 119: Kaul] v. Imperial Oil Co.. $11962 \mid$ S.C.R. 170.

\#) Section 49 Limitition of Actions Act R.S.A. 1955, c. 177.

31 In Berhiheiser V. Berkheiser. |1957| S.C.R. 387. Kelinck. J. said at page 399: "In my opinion. the instrument is to be construed is a srant of profit a prendre for an uncertain term which misht be brought to an end upon the happening of any of the various contingencies for which it provides. It did not bring about that separation of the estate in the mincrals from the cstate in the land apart from the minerals . .." 
adverse possession could rely on his possession.": A second squatter may augment the length of his own occupation by adding that of a previous occupier, at least where there has been no considerable lapse in time between them. The principle is that there must always be someone whom the true owner can sue before possession may be said to be adverse to him.

Normally the time within which action may be brought for the recovery of land is ten years, but complicated situations may arise where a squatter takes possession of land in which successive interests subsist. All Limitation Acts provide special periods for those who have future interests, whether it be a reversion on a lease, a right to foreclose a mortgage or a reversionary beneficial interest in a trust fund.

The question of 'What will amount to possession of land for the purpose of gaining title by limitation?' arises. Section 43 of the Alberta Limitation of Actions Act repeats the wording of the earlier English statute: 'No person shall be deemed to have been in possession of land within the meaning of this Act.merely by reason of having made an entry thereon.' The cases indicate that possession for this purpose entails compliance with some quite stringent requirements. The essential element in possession is the absence of acknowledgment, expressed or implied, of the title of the registered owner. The position is generally stated as it was by Street, J. in Coffin v. North American Land Co.": where he stated, "I think, further, that the plaintiff has failed to shew such a possession as entitles him to assert that he has acquired a title as against the true owners. The Supreme Court in McConaghy v. Denmark, 4 S.C.R. at p. 632, point out that 'by a long unbroken chain of decisions extending over a period of upwards of $\mathbf{4 0}$ years, it has been held by the courts in Upper Canada that the possession which will be necessary to bar the title of the true owner must be an actual. constant, visible occupation by some person or persons ... to the exclusion of the true owner for the full period of 20 years.' The period is now reduced, but the tendency since McConaghy v. Denmark has been more than ever in the direction of requiring satisfactory proof of a possession answering in all respects the conditions above indicated." This case was one in which the possession was held not to be continuous and Street, J., held that": "the acts done in the winter did not constitute an occupation of the property to the exclusion of the right of the true owner, but were mere acts of trespass, covering necessarily but a very short portion of the winter, and that the possession must be taken to have been vacant for the remainder of it. The right of the true owner would attach upon each occasion when the possession became thus vacant, and the operation of the Statute of Limitations would cease until actual possession was taken in the spring again by the plaintiff ..." Coffin v. North American Land Co. establishes that the possession must be continuous to be effective. That the possession must also be exclusive was demonstrated by the decision in Fox v. Ross": when Sir William Mulock C.J. Ex.D. stated: "The lawful owner was not prevented from taking peaceable possession, and there was no trespasser against whom he could have 
maintained an action to recover the land." In both these cases the claimant of the land had relinquished possession during the winter months and when he re-entered each spring his possession began from a later starting point. However, some land is incapable of being effectively possessed during the winter and it would be desirable to take this factor into account. Climatic factors should be taken into account when considering the continuity and exclusiveness of possession. In Possession in the Conmon Law, Pollock and Wright advert to this, ${ }^{35}$ "What kind of acts, and how many, can be accepted as proof of exclusive use, must depend to a great extent on the manner in which the particular kind of property is commonly used. When the object is as a whole incapable of manual control, and the question is merely who has de facto possession, all that a claimant can do is to show that he or someone through whom he claims has been dealing with that object as an occupying owner might be expected to deal with it, and that no one else has done so." That if others do the same acts with relation to the land that the claimant does, his possession cannot be said to be exclusive was demonstrated by the English case of Fowley Marine v. Gafford $^{3 n}$ where Megaw, J. said, "I do not think that it is open to the plaintiff, who seeks to found an action for trespass on the basis, simply, of exclusive possession in himself, to nullify the evidence of equivalent acts of concurrent possession by others such as have been proved in this case, by saying that he or his predecessors must be assumed to have tolerated them because they did no harm."

Whereas taxes paid by the squatter will generally be some evidence of his own possession, if taxes are paid at the request of the registered proprietor or his agent they will be treated as an acknowledgment of his title and so a tenancy at will:i or tenancy at sufferance will be held to have arisen. A mere receipt of rents and profits will be regarded as tantamount to physical possession in many circumstances. For the purposes of the Land Titles Act possession "when applied to persons claiming title to land means also alternatively the reception of the rents and profits thereof.":ik

\section{The Procedure in Alberta}

Since sec. 73 of the Land Titles Act has been incorporated in the statute, the proper course for a squatter to take is to obtain a judgment declaring that he "is entitled to the exclusive right to use the land or that he be quieted in the exclusive possession thereof." Since the judgment does not alter, but merely declares pre-existing rights in the land, it ought, on principle, to be unnecessary. Often the registered owner will be concerned to contest on a factual basis the granting of a declaration of entitlement to an occupier. If the registered owner cannot be found service may be made substitutionally by serving relatives or publishing notices in newspapers, as it was effected in Wallace $v$. Potter:" All those who appear to have a real interest in objecting to the grant of the declaration should generally be joined as defendants. 
This is so that they will have a chance to be represented and because the declaration made in the absence of such interested parties but which affects their right will not bind them. Because of this judges may be reluctant to make declarations concerning the rights of absent parties." For this reason, it may be desirable to join all parties. It is conceivable that a defendant may not wish to go to the expense of entering a defense, and then the courts may not wish to make a declaration on the grounds that there is no live issue or real dispute between the parties. It is, however, probably in the public interest that there should be a declaration.

Sec. 73 (2) provides further that: "At the expiration of three months after the filing thereof, the Registrar shall, unless he is satisfied that an appeal from the judgment is being taken, make, upon the certificate of title in the register, a memorandum cancelling the certificate of title, either wholly or partially, according to the tenor of the judgment and setting forth the particulars of the judgment." This would seem to be a measure exhorting the Registrar to let the register declare the established right of the squatter. Whereas the act of the Registrar in making the entry usually creates the right, here it follows the existence of the right. However theoretically unimportant the judgment and the registration thereof may be with respect to the rights of the parties, the cases" show that until the judgment is obtained and registered the squatter is liable to lose the land. Whether the mere obtaining of a judgment would be sufficient to prevent subsequent loss to the occupier or whether it must be registered as well is a point not yet explored by their decision. On one hand, the owner who is now barred from recovering the land should not have notice of the rights of the squatter, which a declaratory judgment would surely give. On the other hand, the primary purpose of the register is to give notice of rights subsisting in land.

The squatter obtains a new estate of his own but it is subject to any third party rights, such as easements or restrictive covenants which run with the land and have not been extinguished. The estate obtained will generally be a fee simple, but it may not be. It is possible for a squatter to occupy against a tenant and obtain a leasehold estate. The limitation period for the landlord's action to regain possession will commence on the determination of the original lease. The adverse occupant of leasehold land will nearly always be obliged to pay the rent and, according to the basis on which the rent is paid, will become a periodic tenant. If he takes advantage of the previous tenant's lease he may be estopped from denying that he has adopted it, and will therefore make himself subject to the covenants therein.

The Land Titles Act is designed to substitute a system of absolute ownership in land for the common law arrangement of competing rights to possession of the land, and it might, therefore, have been preferable to exclude the doctrine of title by limitation as this is merely a facet of the older system. It would be impossible now to expunge the anachronism in Alberta since it has been received in several decisions and many 
obiter dicta, as well as by the modification in the Act itself. Since the doctrine of title by limitation has become entrenched it should not be curtailed by the restriction that a subsequent conveyance will defeat the statutory occupant's title. There is the practical difficulty that while an inspection must reveal a squatter in the course of acquiring title because his possession must be continuous and notorious, it may not necessarily disclose one who has acquired a title by possession. However, it is unlikely that one who has gained title thus will not be in possession. The course taken by Alberta has made it possible for land to be kept useful and productive by persons who were permitted to hope it would one day be theirs. Other provinces have not accepted the proposition that the doctrine of title by limitation prevails over the indefeasibility section appearing in the Act providing for registered conveyancing. This may have been a wise choice from the standpoint of legal theory. 